\title{
PERBANDINGAN EFEKTIVITAS KONSELING KELOMPOK CBT DENGAN PASSIVE VS ACTIVE MUSIC THERAPY UNTUK MEREDUKSI ACADEMIC ANXIETY
}

\author{
Dominikus David Biondi Situmorang ${ }^{1}$, Mulawarman ${ }^{2}, M^{\prime}$ ungin Eddy Wibowo \\ ${ }^{1}$ Prodi Bimbingan dan Konseling, Universitas Katolik Atma Jaya, Indonesia \\ ${ }^{2}$ Prodi Bimbingan dan Konseling, Pascasarjana, Universitas Negeri Semarang, Indonesia \\ E-mail: david.biondi@atmajaya.ac.id
}

\begin{abstract}
ABSTRAK, Tujuan penelitian ini untuk mengetahui efektivitas pelaksanaan layanan konseling kelompok pendekatan cognitive behavior therapy (CBT) dengan teknik passive music therapy dan active music therapy dalam mereduksi academic anxiety mahasiswa BK Unika Atma Jaya penyusun skripsi. Penelitian ini menggunakan desain quasi-eksperimental dengan repeated measures (pretest, posttest, dan follow-up). Konseling kelompok dilaksanakan selama 5 pertemuan (masing-masing 100 menit), dan follow-up dilakukan setelah 2 minggu diberikan treatment. Subjek penelitian yang digunakan dalam penelitian ini yaitu 14 mahasiswa yang dibagi menjadi dua kelompok. Pemilihan subyek menggunakan teknik purposive sampling yaitu didasarkan pada kriteria academic anxiety yang diperoleh dari academic anxiety scale $\left(\mathrm{r}_{\mathrm{xy}}=0.536-0.823\right.$, koefisien alpha $\left.=0.963\right)$. Hasil penelitian menunjukkan bahwa pada saat pretest vs posttest, konseling kelompok pendekatan CBT dengan passive music therapy $(\mathrm{MD}=47,000)$ lebih efektif untuk mereduksi academic anxiety dibandingkan dengan active music therapy $(\mathrm{MD}=42,000)$. Pada pretest vs follow-up, active music therapy $(\mathrm{MD}=45,714)$ lebih efektif untuk mereduksi academic anxiety dibandingkan dengan passive music therapy ( $\mathrm{MD}=40,857)$. Selanjutnya pada posttest $v$ s follow-up, active music therapy $(\mathrm{MD}=3,714)$ lebih efektif untuk mereduksi academic anxiety dibandingkan dengan passive music therapy yang mengalami kenaikkan academic anxiety ( $\mathrm{MD}=-6,143)$ setelah dua minggu diberikan treatment. Teknik Passive dan Active Music Therapy yang diintegrasikan dalam konseling kelompok pendekatan CBT tidak hanya dapat mengatasi masalah individu, tetapi juga dapat membantu individu menganalisis pikiran dan perilaku mereka sendiri, melalui aktivitas mendengarkan musik secara pasif dan memainkan musik secara aktif.
\end{abstract}

Kata kunci: konseling kelompok, cognitive behavior therapy, passive music therapy, active music therapy, academic anxiety

\section{THE COMPARISON OF CBT COUNSELING WITH PASSIVE VS ACTIVE MUSIC THERAPY TO REDUCE ACADEMIC ANXIETY}

\begin{abstract}
The purpose of this research is to know the effectiveness of counseling group implementation of cognitive behavior therapy (CBT) approach with passive music therapy and active music therapy technique in reducing academic anxiety student of BK Unika Atma Jaya as the undergraduate thesis compilers. This study used a quasi-experimental design with repeated measures (pretest, posttest, and follow-up). Group counseling was conducted for 5 meetings (@100 minutes), and follow-up was performed after 2 weeks of treatment. Research subjects used in this study are 14 students divided into two groups. Subject selection using purposive sampling technique that is based on academic anxiety criteria obtained from academic anxiety scale $(r x y=0.536-0.823$, coefficient alpha $=0.963)$. The results showed that during pretest vs. posttest, CBT group counseling with passive music therapy ( $M D=47,000)$ was more effective for reducing academic anxiety compared to active music therapy $(M D=42,000)$. In pretest vs follow-up, active music therapy $(M D=45,714)$ was more effective for reducing academic anxiety compared with passive music therapy $(M D=40,857)$. Furthermore, posttest vs. follow-up, active music therapy $(M D=3,714)$ was more effective for reducing academic anxiety compared with passive music therapy with an increased academic anxiety $(M D=-6,143)$ after two weeks of treatment. Passive and Active Music Therapy techniques that are integrated into CBT group counseling approach not only can solve individual problems but also can help individuals analyze their own thoughts and behaviors, through passively listening to music and playing music actively.
\end{abstract}

Keywords: group counseling, cognitive behavior therapy, passive music therapy, active music therapy, academic anxiety

\section{PENDAHULUAN}

Dewasa ini, skripsi merupakan tugas akhir yang mengakibatkan kecemasan yang tinggi bagi sebagian besar mahasiswa di Indonesia (Situmorang, 2017a, 2017b, 2018). Rasa cemas terhadap skripsi seperti ini merupakan bentuk academic anxiety di tingkat perguruan tinggi (Ottens, 1991). Banyak di antara mahasiswa yang masih belum memiliki kecakapan menulis yang mumpuni, serta tidak adanya ketertarikan terhadap penelitian. Lebih lanjut, rendahnya motivasi berprestasi dan kreativitas mahasiswa dalam upaya penyelesaian tugas akhir ini, merupakan beberapa prediktor yang dapat menjadi sorotan (Situmorang, 2016). Jika hal ini terus dibiarkan, maka akan mengakibatkan gejala-gejala negatif dalam aspek fisik maupun psikis yang dapa menghambat mahasiswa dalam proses studi mereka. Sebagian besar 
mahasiswa yang mengalami academic anxiety terhadap skripsi ini akan cenderung melakukan hal-hal negatif yang dapat merugikan dirinya sendiri, terutama melakukan hal-hal yang non-produktif sehingga cenderung menjadi procrastinator (Situmorang, 2017b, 2018).

Mengenai hal tersebut, dirasa cukup penting untuk yang bersifat fenomena ini di bagian hulu, dan melakukan layanan intervensi yang bersifat curative untuk mengobati mereka yang telah mengalami academic anxiety ini di bagian hilir (Situmorang, 2017a). Para konselor pendidikan di perguruan tinggi diharapkan untuk selalu bersikap pro-aktif dalam mencegah maupun mengobati para mahasiswa yang mengalami academic anxiety terhadap skripsi ini. Selain itu juga, para konselor pendidikan diharapkan dapat melakukan sebuah layanan intervensi konseling yang lebih efektif dan optimal dala menanggulangi permasalahan ini. Salah satu layanan intervensi konseling modern yang ditawarkan oleh integrative approach adalah melalui musik (Capuzzi \& Gross, 2011; Sharf, 2015; White \& Davis, 2011).

Penggunaan musik dalam konseling dapat meningkatkan produksi keempat hormon positif yang ada di dalom tubuh mansin yatu endorphin, dopang serotonin, de oksto serotin, dan ols positif tesebut dapat membuat tubah menjadi lebih rileks, mereduksi kecenasan atau stres, Meningkatkan kebahagiaan, meningkatkan kecerdasan, dan meningkatkan asa percaya diri (Mucci \& Mucci, 2002; Djohan, 2006).

Pemberian musik sebagai salah satu teknik dalam layanan intervensi untuk membantu mahasiswa dalam mereduksi academic anxiety akan jauh lebih efektif dibandingkan dengan layanan intervensi konseling konvensional yang selama ini dilakukan oleh konselor pendidikan, karena dengan musik mahasiswa dapat mereduksi kecemasannya terhadap shipsir da meningatan rasa percaya diringa dalm menyelesian mening

Sejak tahun 1992, Gladding (2016) memperkenalkan penggunaan musik dalam konseling. Musik digunakan sebagai media untuk menenangkan, dan membantu konseli untuk merasa nyaman, sehingga proses konseling menjadi lebih efekti. Penggunaan musik dalam proses konseling dikenal sebagai $m u s$ therapy. Capuzzi \& Gross (2011) dan Sharf (2015), mengkaj bahwa music therapy sebagai salah satu bentuk intervensi terapi ekspresif/seni kreatif dalam pendekatan konseling integrative (integrative approach), yang dapat diterapkan dalam proses konseling.

Gladding (2016) menyarankan bahwa dalam proses konseling yang modern diharapkan para konselor proses kes terhadap konseli. Salah stu tear ser yag dopt terhadap kapat Siapor musk. gender, suku, agama, ras, latar belakang pendidikan, dan gender, suku, agama, ras,
Dalam penerapannya, music therapy dibagi menjadi dua, yaitu passive music therapy dan active music therap (Wigram, Pedersen, \& Bonde, 2002). Passive music therapy adalah pemberian terapi musik yang dilakuka dengan cara mengajak konseli untuk mendengarka sebuah instrumen tertentu secara seksama. Sementara, active music therapy adalah proses pemberian terap musik yang dilakukan dengan cara mengajak konsel untuk memainkan sebuah instrumen, bernyanyi, maup menciptakn lou Keda teknik terapi mik maupun (n)

Dalam ranah bimbingan dan konseling, konseling kelompok adalah proses interpersonal yang dipimpin ole konselor yang terlatih secara profesional dan dilaksanakan dengan individu-individu yang sedang menghadap problem-problem perkembangan khusus. Hal itu berfokus pada pikiran, perasaan, sikap, nilai, tujuan tingkah laku dan tujuan individu dan grup secara keseluruhan (Gibson \& Mitchell, 2011; Wibowo, 2005).

Wigram, Pedersen, \& Bonde (2002) mengatakan bahwa perkembangan music therapy di dunia dewasa ini dalam praktiknya banyak berpusat pada teori Behavior, yang secara spesifik lebih mengarah pada Cognitive Behaviour Therapy (CBT). Penelitian mutakhir mengenai music therapy yang berpusat pada teori CBT dalam pelaksanaan konseling telah banyak dilakukan, yaitu antaranya penelitian yang dilakukan oleh Baker, Gleadhil, \& Dingle (2007), Fredenburg \& Silverman (2014), Rogers et al. (2007), Situmorang (2018), Vargas (2015), Zhang et al. (2017).

Berdasarkan teori Music Therapy based on Cognitive Behavior Therapy (Wigram, Pedersen, \& Bonde 2002), seorang mahasiswa yang mengalami academic anxiet disebabkan oleh adanya karena adanya distorsi kognitif tau pikiran-pikiran negatif terkait ketids kognitif pirit ketidakberdayaan tau kognitif terbentuk dari core belief yang telah menetap
yaitu merupakan keyakinan paling dasar tentang diri, yaitu merupakan keyakinan paling dasar tentang diri,
adanya keyakinan tidak mampu secara akademik dan adanya keyakinan tidak mampu secara akademik dan
keyakinan tidak berdaya, keyakinan-keyakinan ini terbentuk berdasarkan pengalaman atau peristiwa yan dialami oleh individu. Sehingga ketika individu mengalami masalah terkait academic anxiety, maka hal yang perlu untuk dilakukan adalah dengan membantu individu menstruktur kembali pikiran-pikiran negatif yang dimiliki menuju pikiran-pikiran yang lebih adaptif.

Dengan menggunakan teknik passive music therapy dan active music therapy yang berpusat pada CBT ini diharapkan dapat membantu mereka menyadari pikiranpikiran negatif yang menyebabkan hal tersebut, kemudian mengevaluasi pikirannya, dan selanjutnya mereka bereksplorasi alternatif untuk mengubah pikiran negatif tentang dirinya dan lingkungannya melalui aktivitas mendengarkan musik secara reseptif/pasif dengan guided imagery dan aktivitas musik secara aktif melalu menciptakan lagu (composing), improvisasi, dan re- creating music. Hal lain yang tidak kalah pentingnya dari pemberian music therapy ini ialah untuk membantu konsel meningkatkan produksi 4 hormon positif yang dimiliki oleh setiap individu, yaitu endorphin, dopamin, serotonin, dan oksitosin (Mucci \& Mucci, 2002) yang berperan sebagai pemicu kebahagiaan yang diharapkan. Fungsi dari keempat hormon positif tersebut dapat membuat tubuh menjadi lebih rileks, sehingsa dapat mereduksi kecemasa atau stres yang dialami oleh individu.

Kenyataan di Indonesia, penerapan dan penelitian terapi musik dalam praktik konseling masih jarang ditemukan. Penelitian mengenai pengaruh musik sebagai media terapi terhadap stres akademik mahasiswa pernah dilakukan oleh Rosanty (2014). Dari hasil penelitian tersebut, musik dapat digunakan sebagai intervensi untuk menurunkan stres akademik yang dialami oleh mahasiswa. Namun, penelitian ini hanya membuktikan penggunaan musik Mozart sebagai media penurunan stres akademik secara pasif, dan belum mengkaji tentang pemberian musik sebagai suatu teknik dari integrative approach yang dapat dintegrasikan ke dalam praktik konseling dengan pendekatan konvensional.

Berdasarkan hal tersebut, dirasa perlu untuk melakukan penelitian lebih lanjut mengenai pemberian terapi musik dengan teknik passive music therapy dan passive music therapy yang diintegrasikan dengan salah satu pendekatan konseling konvensional yaitu CBT, guna membuktikan efektivitasnya dalam mereduksi academic anxiety mahasiswa penyusun skripsi. Hipotesis yang diajukan adalah terdapat perbedaan efektivitas konseling kelompok CBT dengan teknik passive music therapy dan passive music therapy dalam mereduksi academic anxiety mahasiswa penyusun skripsi.

\section{METODE}

Penelitian ini menggunakan konseling kelompok CBT dengan teknik passive music therapy dan active music therapy sebagai variabel bebas atau tritmen, dan academic anxiety sebagai variabel terikat. Konseling kelompok CBT dengan teknik passive music therapy adalah layan Bang dibeik te yang menunjukkan acteris sehingga dapat mecemasan yang dialami, kemudian mengevaluasi kecemasannya tersebut berdasarkan pengalaman masa lalunya yang tidak menyenangkan. Selanjutnya anggota kelompok diajak untuk berdamai dengan pengalaman masa lalunya tersebut, dan mengoptimalkan kemampuan yang dimiliki agar dapat menyelesaikan skripsi dengan baik melalui aktivitas mendengarkan musik secara reseptif/pasif dengan guided imagery. Sementara, konseling kelompok CBT dengan teknik active music therapy adalah layanan yang diberikan untuk membantu angrota kelompok yang menunjukkan academic anxiety, sehingos dopat membantu mere untuk mampu menyadari pikiran-pikiran negatif yang menyebabkan hal tersebut, kemudian mengevaluasi pikirannya, dan selanjutnya mereka bereksplora alternatif untuk mengubah pikiran negatif tentang diriny dan lingkungannya melalui aktivitas musik secara aktif yaitu menciptkan lagu (composing), improvisasi, dan recreating music.

Selanjunnya, academic anxiety adalah suatu dorongan pikiran dan perasaan yang tidak menyenangkan dalam diri mahasiswa, sebagai akibat dari perasaan khawatir berkaitan dengan proses penyusunan skripsi. Di mana dalam kecemasan terdapat lima indikator, yaitu pola kecemasan yang menimbulkan aktivitas mental (pattern of anxiety-engendering mental activity), perhatian yang menunjukkan arah yang salah (misdirected attention), distres secara fisik (physiological distres), dan perilak yang kurang tepat (inappropriate behaviors)

Subjek penelitian dalam penelitian ini adalah mahasiswa BK Unika Atma Jaya yang memilik academic anxiety yang sedang sampai dengan tinggi Subyek penelitian yang digunakan dalam penelitian in yaitu 14 mahasiswa. Pemilihan subyek ini menggunaka teknik purposive sampling (non-random). Pemilih subyek penelitin didsorkan pal kiteri inslus du

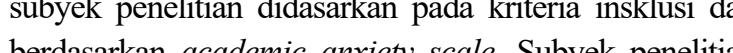
yang telah dipilih berdasarkan academic anxiety scale hasilnya dijadikan sebagai pretest. Pretest ini dilakukan untuk mengetahui gambaran awal kondisi academic anxiety mahasiswa sebelum diberikan treatment dan kemudian untuk dibandingkan dengan posttest dan follow-

Instrumen utama yang digunakan dalam penelitian adalah academic anxiety scale yang peneliti kembangka dan mengacu pada teori academic anxiety menurut Ottens (1991). Academic anxiety scale terdiri dari 24 item. Pada alat ukur tersebut peneliti melakukan melakukan proses validasi ahli (expert judgement) den melakun ba in dinyatakan valid $\left(\mathrm{r}_{\mathrm{xy}}=0.536-0.823\right)$ dengan koefisien dinyatakan valid $\left(\mathrm{r}_{\mathrm{r},}\right.$

Metode yang digunakan ialah quasi-eksperimental dengan repeated measures. Penelitian ini menggunaka tiga kali pengukuran (pretest, posttest, follow-up). Pretes berupa pemberian intrumen pengumpulan data (academic anxiety scale) sebelum diberikan treatment. Sementara treatment yang diberikan adalah konseling kelompok CBT dengan teknik passive music therapy dan active music therapy dilaksanakan sebanyak 5 pertemuan dalan kelompok yang berbeda, dengan frekuensi pertemuan satu kali dalam semingou, dan durasi 100 menit setiap pertemuan Posttest berupa pemberian intrumen pengumpulan data yang diberikan seta instran pengum be dan dilaksankan du mingen setelah dibeikn

Teknik analisis yang digunakan dalam penelitian ini ialah one-way Analysis of variance (ANOVA) repeated 
measures dengan menggunakan bantuan program Microsoft Excel 2010 dan IBM SPSS for windows versi 23 Tujuan dari penggunaan teknik analisis ini ialah untuk menguji hipotesis guna mengetahui perbedaan efektivitas konseling kelompok CBT dengan teknik passive music therapy dan active music therapy berdasarkan data pretest, posttest, dan follow-up.

\section{HASIL DAN PEMBAHASAN}

Konseling Kelompok CBT dengan Passive Music Therapy

Data yang terkumpul (pretest, postest, followup) ditabulasikan sebelum dilakukan analisis (Tabel 1 . dan Gambar 1.). Kondisi academic anxiety kelompok yang diberikan konseling kelompok CBT dengan passive music therapy sebelum mendapatkan treatment berada pada kondisi yang tinggi. Setelah mendapatkan treatment, tingkat academic anxiety mahasiswa menurun menjadi rendah, namun pada saat follow-up mengalam peningkatan sedikit academic anxiety kembali.

Tabel 1. Data Deskriptif Skor Academic Anxiety Kelompok A

\begin{tabular}{ccccc} 
No. & Mahasiswa & Pretest & Posttest & Follow-up \\
\hline 1. & AMYP & 97 & 45 & 63 \\
2. & RC & 100 & 50 & 43 \\
3 & MM & 95 & 52 & 65 \\
4 & FAO & 92 & 53 & 58 \\
5 & RRC & 87 & 43 & 50 \\
6 & TK & 90 & 49 & 51 \\
7 & MDA & 102 & 42 & 47
\end{tabular}

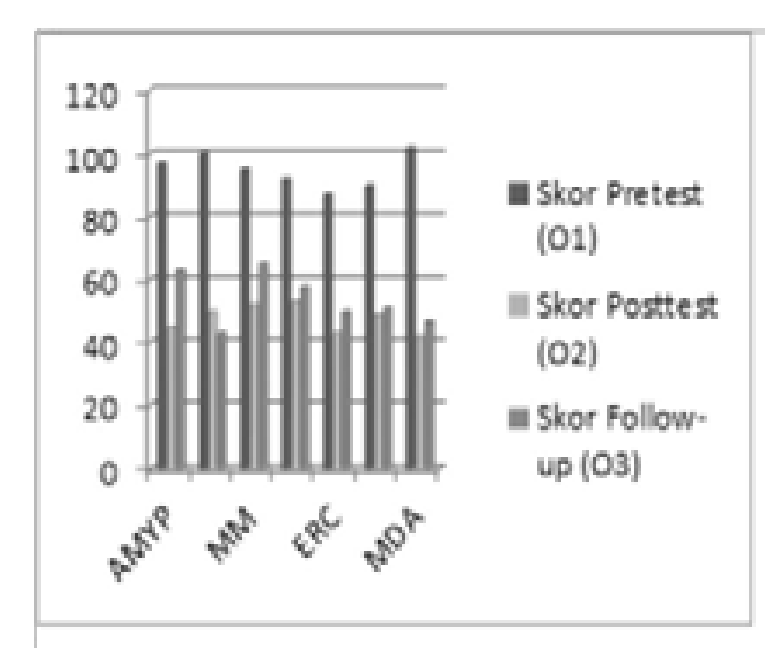

Gambar 1. Grafik Academic Anxiety Mahasiswa Kelompok A

Berdasarkan hasil pretest rata-rata tingkat academic anxiety mahasiswa termasuk dalam kriteria tinggi $(\mathrm{M}=$ 94.71, $\mathrm{SD}=5.407)$. Setelah diberikan treatment berup konseling kelompok pendekatan CBT dengan teknik passive music therapy, academic anxiety mahasiswa mengalami penurunan yang sangat drastis pada saa posttest $(\mathrm{M}=47.71, \mathrm{SD}=4.386)$. Namun setelah dua minggu pemberian treatment, terjadi sedikit peningkatan pada academic anxiety mahasiswa saat follow-up $(\mathrm{M}=$ $53.86, \mathrm{SD}=8.295$ ). Sehinga dari hasil analisis ( 53.86, SD - 8.295). Senge CBT deng CBT dengan te bik pasipe music herapy efektif dalan $<0.01)$
$<$.

Tabel 2. Hasil One-Way ANOVA Repeated Measures

Kelompok A

\begin{tabular}{cccc}
\hline Parameter & Pretest & Posttest & Follow-up \\
\hline Mean & 94.71 & 47.71 & 53.86 \\
Std. Deviation & 5.407 & 4.386 & 8.295 \\
F (2,12) & 117.505 & & \\
$p$ & $<0,01$ & & \\
& & &
\end{tabular}

Hasil analisis perbandingan (pairwise) juga menunjukkan besaran nilai perolehan pada pengukuran academic anxiety (Tabel 3. dan Gambar 2.). Besaran nilai penurunan academic anxiety dari efektivitas konseling kelompok pendekatan CBT dengan teknik passive musi therapy pada pretest vs posttest $(\mathrm{MD}=47.000, \mathrm{SE}=$ $2.795, \mathrm{p}<0.01)$. Kemudian, pada pretest vs follow-up $(\mathrm{MD}=40.857, \mathrm{SE}=4.056, p<0.01)$. Pada posttest vs follow-up $(\mathrm{MD}=-6.143, \mathrm{SE}=3.011, p>0.01)$.

\section{Tabel 3. Hasil Pairwise Comparisons Kelompok A}

\begin{tabular}{|c|c|c|c|c|}
\hline No & Perbandingan & MD & SE & p \\
\hline 1 & Pretest vs Posttest & 47.000 & 2.795 & $<0.01$ \\
\hline 2 & Pretest vs Follow-up & 40.857 & 4.056 & $<0.01$ \\
\hline 3 & Posttest vs Follow-up & -6.143 & 3.011 & $>0.01$ \\
\hline
\end{tabular}

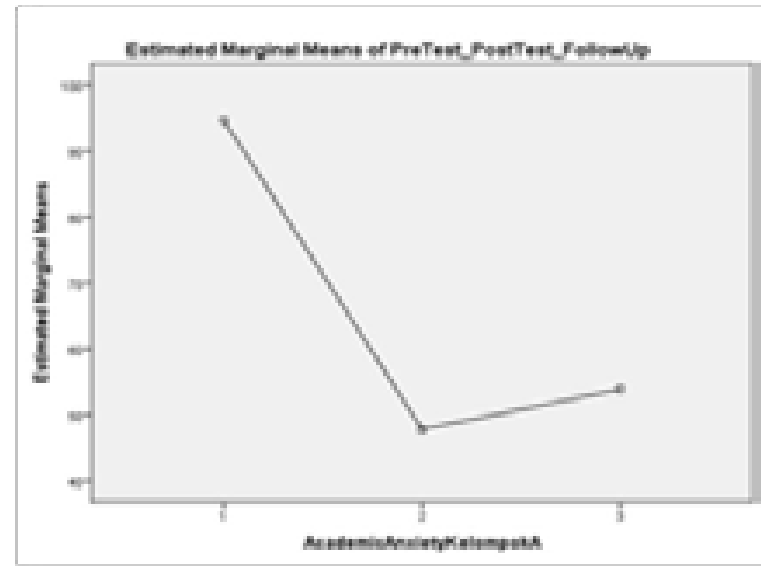

Gambar 2. Estimated Marginal Means Kelompok A

Berdasarkan hasil perolehan, maka dapat disimpulkan bahwa konseling kelompok pendekatan CBT dengan teknik passive music therapy secara signifikan dapat mereduksi academic anxiety mahasiswa BK Unika Atma Jaya pada saat pretest vs posttest dan pretest vs follow-up, namun pada saat posttest vs follow-up terjadi sedikit peningkatan

Konseling Kelompok CBT dengan Active Music Therapy

Data yang terkumpul (pretest, postest, follow-up) ditabulasikan sebelum dilakukan analisis (Tabel 4. dan Gambar 3.). Kondisi academic anxiety kelompok yang diberikan konseling kelompok CBT dengan active music therapy sebelum mendapatkan treatment berada pada kondisi yang tingsi. Setelah mendapatkan treatment, tingkat academic anxiety mahasiswa menuru meatment, rendah, kemudian pada saat follow-up mengalami penurunan kembali pada academic anxiety.

Tabel 4. Data Deskriptif Skor Academic Anxiety
Kelompok B

\begin{tabular}{ccccc} 
No. & Mahasiswa & Pretest & Posttest & Follow-up \\
\hline 1. & PA & 93 & 49 & 48 \\
2. & ST & 99 & 55 & 55 \\
3. & BKK & 95 & 59 & 61 \\
4. & SS & 92 & 63 & 50 \\
5. & OE & 87 & 44 & 39 \\
6. & VOC & 93 & 44 & 42 \\
7. & TD & 89 & 40 & 33
\end{tabular}

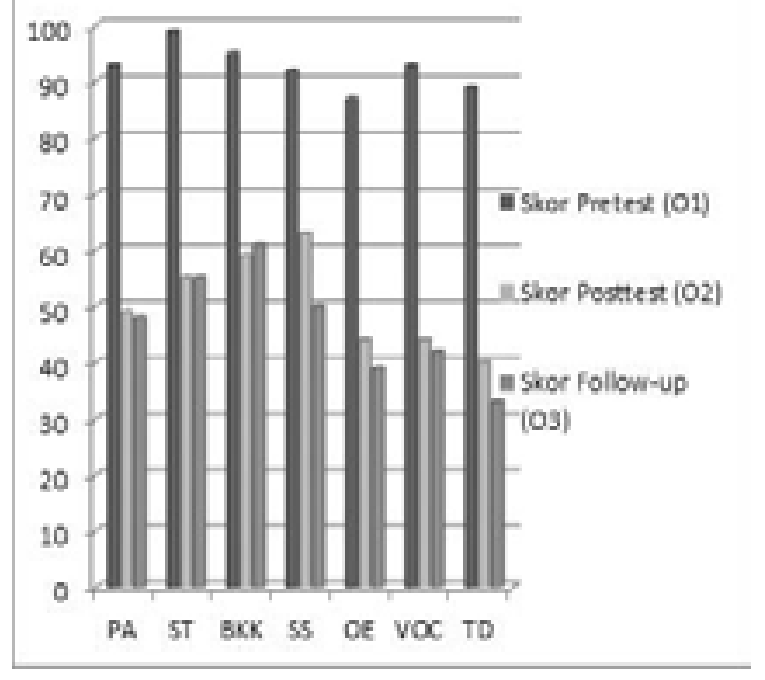

Gambar 3. Grafik Academic Anxiety Mahasiswa Kelompok B

Berdasarkan hasil pretest rata-rata tingkat academic anxiety mahasiswa termasuk dalam kriteria tinggi $(\mathrm{M}=$ $92.57, \mathrm{SD}=3.910$ ). Setelah diberikan treatment berupa konseling kelompok pendekatan CBT dengan teknik active music therapy, academic anxiety mahasiswa mengalami penurunan yang sangat drastis pada saat posttest $(\mathrm{M}=50.57, \mathrm{SD}=8.619)$. Kemudian, setelah dua minggu pemberian treatment, terjadi penurunan kembal pada academic anxiety mahasiswa saat follow-up $(\mathrm{M}=$ 46.86, $\mathrm{SD}=9.616$ ). Sehingga dari hasil analisis (Tabe 5.) menunjukkan bahwa konseling kelompok pendekatan CBT dengan teknik passive music therapy efektif dalam mereduksi academic anxiety mahasiswa ( $\mathrm{F}=213.495$, $\mathrm{p}$ $<0.01$ ).

Tabel 5. Hasil One-Way ANOVA Repeated Measures Kelompok B

\begin{tabular}{cccc}
\hline Parameter & Pretest & Posttest & Follow-up \\
\hline Mean & 92.57 & 50.57 & 46.86 \\
Std. Deviation & 3.910 & 8.619 & 9.616 \\
F (2,12) & 213.495 & & \\
$p$ & $<0,01$ & & \\
& & &
\end{tabular}

Hasil analisis perbandingan (pairwise) juga menunjukkan besaran nilai perolehan pada pengukuran academic anxiety (Tabel 6. dan Gambar 4.). Besaran nilai penurunan academic anxiety dari efektivitas konseling kelompok pendekatan CBT dengan teknik active music therapy pada pretest vs posttest $(\mathrm{MD}=42.000, \mathrm{SE}=$ 2.726, $\mathrm{p}<0.01$ ). Kemudian, pada pretest vs follow-up $(\mathrm{MD}=45.714, \mathrm{SE}=2.643, p<0.01)$. Pada posttest vs follow-up $(\mathrm{MD}=3.714, \mathrm{SE}=1.924, p>0.01)$.

Tabel 6. Hasil Pairwise Comparisons Kelompok B
\begin{tabular}{ccccc} 
No. & Perbandingan & $M D$ & $S E$ & $p$ \\
\hline 1. & Pretest vs Posttest & 42.000 & 2.726 & $<0.01$ \\
2. & Pretest vs Follow-up & 45.714 & 2.643 & $<0.01$ \\
3. & Posttest vs Follow-up & 3.714 & 1.924 & $>0.01$
\end{tabular}

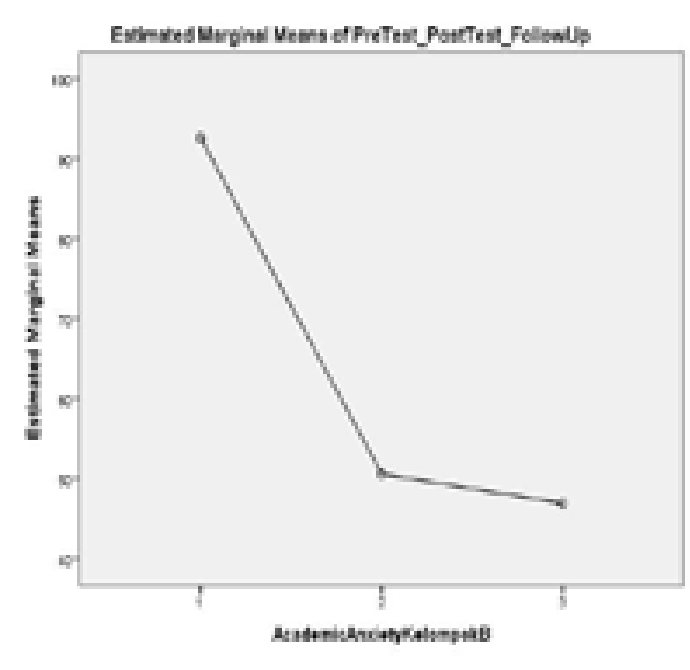

Gambar 4. Estimated Marginal Means Kelompok B Berdasarkan hasil perolehan, maka dapat disimpulkan bahwa konseling kelompok pendekatan $\mathrm{CBT}$ dengan teknik active music therapy secara signifikan dapat 
mereduksi academic anxiety mahasiswa BK Unika Atma Jaya pada saat pretest vs posttest, pretest vs follow-up, dan posttest vs follow-up.

Perbandingan Efektivitas Konseling Kelompok CBT dengan Passive vs Active Music Therapy

Berdasarkan hasil uji Repeated Measures ANOVA pada test of within-subjects effect didapatkan data bahwa kelompok A (dengan teknik passive music therapy) dengan $\mathrm{F}=117.505$ dan $p=0,00<0,01$, serta kelompok $\mathrm{B}$ (dengan teknik active music therapy) dengan $\mathrm{F}=213.495$ dan $p=0,00<0,01$. Dapat disimpulkan bahwa Ha diterima dan Ho ditolak, sehinge terdapt perbedan yang dan Ho dist signifikan pada hasil pretest, posttest dan follow-up

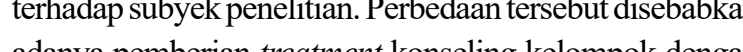
adanya pemberian treatmen konseling kelompok denga pendekatan CBT melalui teknik passive dan active music therapy. Perbedaan efektivitas antara konseling $\mathrm{CB}$ dengan teknik passive dan active music therapy dalam mereduksi academic anxiety mahasiswa dapat dilihat pada tabel 7. berikut:

Tabel 7. Perbandingan Repeated Measures Academic Anxiety Mahasiswa Kelompok Passive dan Active Music Therapy

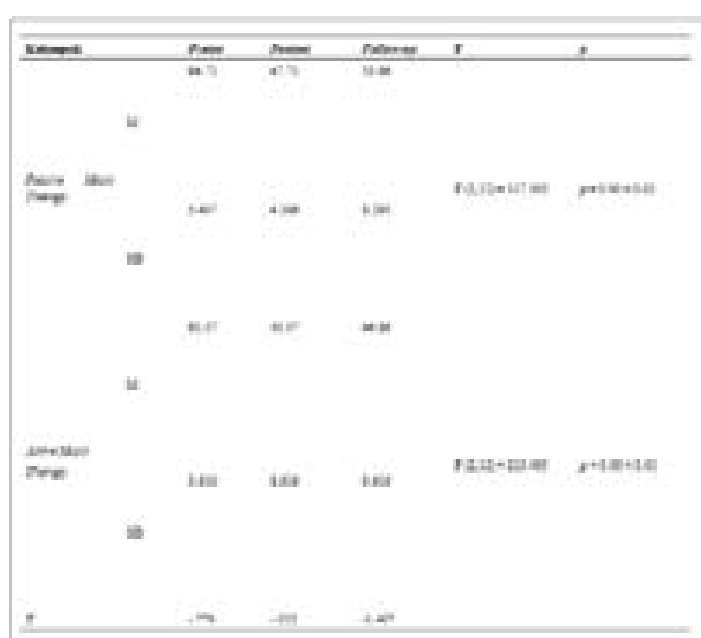

Dari plot perbandingan pereduksian academic anxiety kelompok Adan B di bawah, diperoleh hasil tingkat anxiety kelompok Adan Bdibawah, diperoleh hasil tingk
academic anxiety mahasiswa pada kelompok A (dengan teknik passive music therapy) pada saat pelaksanaan pretest $(\mathrm{M}=94.71, \mathrm{SD}=5.407)$ lebih tinggi secara signifikan di bandingkan pada saat posttest $(\mathrm{M}=47.71, \mathrm{SD}=4.836$, dan pada saat follow up $(\mathrm{M}=53.86, \mathrm{SD}=8.295$ ), walaupu ada kenaikan sedikit academic anxiety mahasiswa dari pada saat posttest ke follow-up $(\mathrm{MD}=-6.143, \mathrm{SE}=3.011)$. Temuan ini sejalan dengan prediksi Ha yang menyataka bahwa konseling kelompok CBT dengan teknik passive music therapy efektif untuk mereduksi academic anxiety mahasiswa.

Selanjutnya, kelompok B (dengan teknik active music therapy) pada saat pelaksanaan pretest $(\mathrm{M}=92.57$, $\mathrm{SD}=3.910$ ) lebih tinggi secara signifikan dibandingkan pada saat posttest $(\mathrm{M}=50.57, \mathrm{SD}=8.619)$, dan pada saat follow-up $(\mathrm{M}=46.86, \mathrm{SD}=9.616)$. Pada kelompok ini, terjadi penurunan kembali academic anxiety mahasiswa dari pada saat posttest ke follow-up ( $\mathrm{MD}=3.714$ $\mathrm{SE}=1.924)$. Temuan ini juga sejalan dan menjawab prediksi Ha yang menyatakan bahwa terdapat perbedaan tingkat keefektifan antara konseling kelompok CBT dengan teknik passive music therapy dan active music therapy terhadap academic anxiety mahasiswa dalam

Berdasarkan tabel 7. di atas juga dapat diketahu bahwa terdapat perbedaan keefektifan konselin kelompok $\mathrm{CBT}$ menggunakan teknik passive musi therapy dan active music therapy dalam mereduks academic anxiety mahasiswa. Hal tersebut dapat diketahu dengan adanya nilai $\mathrm{z}$ pada pretest $(\mathrm{z}=-0.770)$, posttest $(\mathrm{z}=-0.512)$, dan follow-up $(\mathrm{z}=-1.407)$. Lebih lanjut untuk melihat perbedaan yang signifikan pada pengukuran pad penelitian ini dapat dilihat pada tabel 8 . berikut ini.

Tabel 8. Pairwise Comparisons Academic Anxiety Mahasiswa Kelompok Passive dan Active Music Therapy

\begin{tabular}{|c|c|c|c|c|}
\hline \multirow[t]{2}{*}{ Kelompok } & \multirow{2}{*}{$\frac{\text { Perbandingan }}{\text { Pretest vs Posttest }}$} & MD & $\mathbf{S E}$ & $P$ \\
\hline & & 47.000 & 2.795 & .000 \\
\hline $\begin{array}{l}\text { Passive } \\
\text { Music }\end{array}$ & $\begin{array}{l}\begin{array}{l}\text { Pretest } \\
\text { low-up }\end{array} \\
\text { lool- }\end{array}$ & $40.857^{\circ}$ & 4.056 & .000 \\
\hline \multirow[t]{2}{*}{ Therapy } & $\begin{array}{l}\begin{array}{l}\text { Posttest } \\
\text { low-up }\end{array} \\
\text { Fol- }\end{array}$ & -6.143 & 3.011 & .262 \\
\hline & Pretest vs Posttest & 42.000. & 2.726 & .000 \\
\hline \multirow{2}{*}{$\begin{array}{l}\text { Active Mu- } \\
\text { sic Therapy }\end{array}$} & $\begin{array}{lll}\begin{array}{l}\text { Pretest } \\
\text { low-us }\end{array} & \text { Fol- }\end{array}$ & 45.714 . & 2.643 & .000 \\
\hline & $\begin{array}{l}\begin{array}{l}\text { Posttest vs } \\
\text { low-up }\end{array} \\
\text { Fol- }\end{array}$ & $3.714 *$ & 1.924 & .305 \\
\hline
\end{tabular}

Pada tabel 8. dapat diketahui bahwa pada pretest vs posttest passive music therapy ( $(\mathrm{MD}=47.000)$ lebih efektif untuk mereduksi academic anxiety dibandingkan dengan active music therapy $(\mathrm{MD}=42.000)$. Pada pretest vs followup, active music therapy $(\mathrm{MD}=45.714)$ lebih efektif untuk mereduksi academic anxiety dibandingkan dengan passive music therapy $(\mathrm{MD}=40.857)$. Selanjutnya pada posttes vs follow-up, active music therapy ( $\mathrm{MD}=3.714)$ lebih efektif untuk mereduksi academic anxiety dibandingka dengan passive music therapy yang mengalami kenaikkan academic anxiety (MD=-6.143) setelah dua minggu diberikan treatment. Untuk lebih jelasnya dapat dilihat pada gambar 5 . berikut ini:

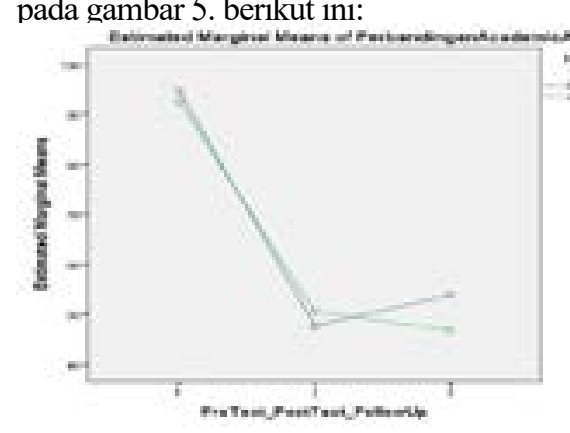

Gambar 5. Plot Perbandingan pereduksian Academic Anxiety kelompok Passive dan Active Music Therapy

Berdasarkan gambar 5. maka dapat dilihat perbandingan konseling kelompok CBT dengan menggunakan teknik passive dan active music therapy dalam mereduksi academic anxiety mahasiswa. Dari tabel 8 dan gambar 5. dapat dilihat bahwa konseling kelompok CBT dengan mengounakan teknik passive music therapy lebih efektif untuk meduks acodemic anxiety pada lebih efektif untuk mereduksi academic anxiety pada saat pretest is pastess semilow $u p$ dan posttest vs follow-mp, active music therapy lebih diber bandingkan dengan passive music therapy.

Berdasarkan hasil penelitian ini menunjukkan bahwa melalui passive dan active music therapy memberikan efek penurunan pada simptom academic anxiety mahasiswa yang sedang mengerjakan skripsi. Hal ini juga didukung oleh hasil wawancara di mana penurunan tingkat academic anxiety yang dirasakan oleh para subyek terjadi setelah mengikuti konseling CBT dengan teknik passive dan active music therapy. Hasil penelitian ini sangat mendukung hasil penelitian yang dilakukan oleh Skudrzyk et al. (2009) balitian yang dilakukan oleh Skudrzyk et al. (2009), bahwa penggunaan nusik dalam proses konseling dapat secara efekif emosi dan kognitif mereka. Inividu dapat mendengarkan lagu, ataupun memainkan alat musik secara aktif. Melalui musik, konselor dapat membuat proses konseling menjadi lebih menarik dan efektif. Senada juga dengan penelitian yang dilakukan oleh Bradley et al. (2008) bahwa melalui musik dapat membantu konselor dan konseli dalam melakukan reframing ide, memfokuskan perspektif, eksternalisasi emosi, dan memperdalam pemahaman dari sebuah pengalaman atau masalah.

Penggunaan musik dalam proses konseling memiliki banyak manfaat yang terapeutik. Glodding (2016) juga menoungk mengun mengurangi, menurunkan dan mentasi kecemasan dan re re Tekn terapi musik. Teknik relaksasi merupakan coping skill yang efektif untuk menurunkan tingkat kecemasan. Keberadaan musik sebagai media terapi ini merupakan salah satu fenomena yang menarik untuk dikaji dan dikembangkan. Musik digunakan sebagai media untuk menenangkan, dan membantu konseli untuk merasa nyaman, sehingga proses konseling menjadi lebih efektif (Capuzzi \& Gross, 2011; Sharf, 2015; Situmorang, 2017a, 2017b, 2018; White \& Davis, 2011).

Temuan penelitian ini juga semakin mendukung temuan yang dilakukan para peneliti lain yang telah membuktikan efetivits integrasi music therapy denga

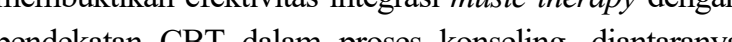
pendera CBT dantaranya Rogese (2007) yan keduanya, selain itu juga Fredenburg dan Silverman (2014), Hui-Chi Li et al. (2015), Vargas (2015), Zhang et al. (2017) yang secara implisit mengintegrasikan music therapy dengan pendekatan CBT. Dalam kelompok passive music therapy, penelitian ini mampu membantu subyek penelitian untuk menyadari kecemasan yang dialami, kemudian subyek penelitian dapat mengevaluas kecemasannya tersebut berdasarkan pengalaman mas lalunya yang tidak menyenangkan. Selanjutnya, subyek penelitian diajak untuk berdamai dengan pengalaman masa lalunya tersebut dan menooptimalkan kemampun yang dimiliki agar dapat menyelesaikan skripsi denga baik bake Sement Sementara, dalam kelonpok active music therapy, penelitian ini dapat membantu subyek penelitian untuk mampu menyadari pikiran-pikiran negatif yang menyebabkan academic anxiety yang dialami, kemudia subyek penelitian dapat mengevaluasi pikiran yang menyebabkan academic anxiety tersebut, dan selanjutnya subyek penelitian dapat bereksplorasi untuk mengubah pikiran negatif tentang dirinya dan lingkungannya melalui aktivitas musik secara aktif, yaitu menciptkan lagu (composing), improvisasi, dan re-creating music (Situmorang, 2018).

Secara ilmiah, musik dapat mempengaruhi tubuh, pikiran dan emosi, sehingga dapat memberikan ketenangan dan kedamaian ketika aktivitas mental meningkat sekaligus dapat mengurangi tekanan akiba keadaan stres atau cemas (Djohan, 2006). Keadaan tersebut mempengaruhi bagian otak manusia yang berhubungan dengan proses emosional terutama paca bagian hipotalamus (Vianna, Barbosa, Carvalhaes, \& Cunha, 2012). Seorang individu yang mengalami anxiety disebabkan oleh produksi hormon tiroksin yang tingg dalam otak manusia. Seseorang yang mengalami proses emosional yang negatif akan merangsang hipotalamus memproduksi hormon tiroksin yang tinggi.

Hal tersebut yang menyebabkan individu mudah lelah, mudah cemas, mudah tegang, mudah takut dan susah tidur, sehingga keadaan individu menjadi kurang optimal. Untuk menanggulangi hal tersebut, menurut Mucci \& Mucci (2002) seseorang harus dapat menyeimbangkan diri dalam setiap kondisi yang dialami. Otak manusia memiliki empat morfin alami tubuh yait hormon positif yang dapat meredakan penyakit dan membuat hidup menjadi bahagia. Morfin tersebut yaitu hormon endorphin, dopamin, serotonin, dan oksitosin. Fungsi dari morfin-morfin alami tersebut dapat membuat tubuh menjadi lebih rileks, sehingga dapat mereduksi kecemasan atau stres.

Wigram, Pedersen, \& Bonde (2002) menjelaskan bahwa salah satu intervensi untuk meningkatkan produk hormon endorphin dan serotonin ialah dengan melakuk relaksasi melalui mendengarkan musik Secara psikologis, musik memiliki hubungan yang positif dalam kehidupan manusia. Musik, dapat membuat seseorang menjadi lebih rileks, mengurangi stres, menimbulkan rasa aman dan sejahtera, meningkatkan rasa bahagia, dan membantu 
melepaskan rasa sakit (Djohan, 2006). Hal ini diperkuat juga oleh penelitian yang dilakukan oleh Laura, Sylvie, an Aurore (2015) dan Zarate (2016) bahwa musik dapat meningkatkan produksi hormon endorphin dan serotonin yang mengakibatkan seorang individu dapat merasa lebih bahagia dan mereduksi kecemasan yang dialami.

Mayoritas subyek mengatakan setelah mendengarkan musik secara pasif dan memainkan musik secara aktif, para subyek merasa lebih rileks, tenang, damai, nyaman sehingga tidak merasa cemas, khawatir, bingung dan yang terpenting yaitu dapat membantu dan memotivasi untuk mengerjakan skripsi tanpa menunda-nunda. Hal ini senada dengan pendapat Djohan (2006) dan hasil penelitian yang dilakukan oleh Bibb, Newton, dan Newton (2015), Fox dan McKinney (2015), Gutiérrez dan Camarena (2015), Hatice Çiftçi dan Öztunç (2015), Lilley, Obercle, dan Thompson (2014), Rosanty (2014), Situmorang (2018), yang menjelaskan bahwa mendengarkan dan memainkan musik secara umum dapat digunakan untuk menyembuhkan stres atau kecemasan, karena musik memiliki kekuatan untuk menciptakan keadaan relaksasi pada individu sehinga keadan rileks ini menyebabkan terjadinya kese ini menyebabkan ter.

Dari hasil penelitian yang telah dilakukan terhadap kelompok A (passive music therapy) dan kelompok B (active music therapy) untuk mereduksi academic anxiety, terdapat perbedaan efektivitas bahwa pada pretest vs posttest, passive music therapy lebih efektif untuk mereduksi academic anxiety dibandingkan dengan active music therapy. Pada pretest vs follow-up, active music therapy lebih efektif untuk mereduksi academic anxiety dibandingkan dengan passive music therapy. Selanjutnya pada posttest vs follow-up, active music therapy lebih efektif untuk mereduksi academic anxiety dengan passive music therapy yang me-ngal kenaik pas kenaiknent Perbed

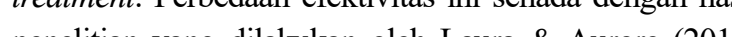
penelitan yang dilakn old Lana \& Aurore (2015) menyatakan bahwa terapi missk aktir lebih efektif dalam mengobati gangguan kecemasan dan depresi yang dialami oleh pasien

Hal tersebut juga senada dengan penelitian yang dilakukan oleh Atiwannapat et al. (2016) yang menyataka bahwa pengurangan gejala major depressive disorder sedikit lebih besar pada kelompok terapi musik aktif dibandingkan dengan kelompok terapi musik pasif. Selain itu juga, ada penelitian lainnya yang dilakukan oleh Ilie (2013) yang menunjukkan bahwa kelompok peserta yang bermain musik ment pertang delam dam kang manya d). musik). Namun, seperti yang diharapkan, peserta dalam kelompok yang mendengarkan musik menunjukkan penurunan yang signifikan juga dalam kadar kortiso walaupun tidak sebesar kelompok yang bermain musik.
Pada kelompok A (passive music therapy), semua anggota kelompok mengalami penurunan academic anxiety secara drastis pada saat pretest vs posttest. Namu pada saat pretest vs follow-up, hanya terlihat ada satu subyek saja yang mengalami perubahan yang sanga mencolok dan subyek yang lainnya tidak mengalam penurunan, malah terlihat peningkatan academic anxiety. Subyek yang tampak mencolok yaitu subjek RC yan mengalami penurunan tingkat academic axxiety cuk mengalami penurunan tingkat academic anxiety cukup tinggi saat posttest vs follow up. Hal ini menandaka bahwa efek dari passive music therapy yang dirasaka subyek RC bertahan dalam jangka waktu yang lama selain itu didukung juga oleh intensitas subyek dalan mendengarkan musik selama dua minggu sebanyak tig

Menurut Berlyne (dalam Djohan, 2010) salah satu faktor yang terkait ketika seseorang mendengarkan da memainkan musik adalah familiaritas, jadi semakin sering seseorang mendengarkan dan memainkan musik, maka nilai hedonisnya akan semakin meningkat. Sementara, pada keenam subyek yang lainnya tampak mengalami kenaikkan skor academic anxiety saat posttest vs followup. Hal ini menunjukkan bahwa passive music therapy

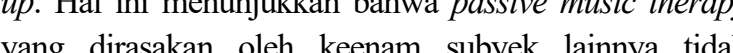
yan

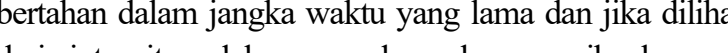

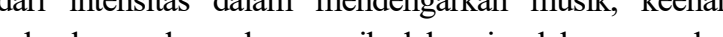
subyek mendengarkan musik dalam jumlah yang cukup sdikit selama dua minggu.

Berbeda halnya dengan yang terjadi pada kelompok B (active music therapy), semua anggota kelompok mengalami penurunan academic anxiety secara drastis pada saat pretest vs posttest. Namun, pada saat pretes vs follow-up, hanya terlihat ada satu subyek saja yang mengalami perubahan yang sangat mencolok dan subyek yang lainnya tidak mengalami peningkatan, malah terlihat penurunan academic anxiety. Subyek yang tampak mencolok yaitu subjek BKK yang mengalami tampak tingkat acalemic amxiety so post test vs follow w . Hape . diras dirasakan subyek BKK tidak dapat bertahan dalam jangk waktu yang lama, selain itu didukung juga oleh kurangny subyek dalam menainkan musk selama dua minggu.

Menurut Berlyne (dalam Djohan, 2010) salah satu faktor yang terkait ketika seseorang mendengarkan dan memainkan musik adalah familiaritas, jadi semakin sering seseorang mendengarkan dan memainkan musik, mak nilai hedonisnya akan semakin meningkat. Satu subyek yang tidak mengalami peningkatan ataupun penurunan (stabil) pada saat pretest vs follow-up yaitu subyek ST Ha ini menunjukkan bahwa efek dari active music therapy yang dira

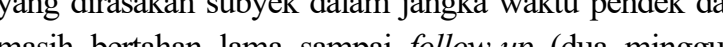
Sedang sedangkan pada kelima subyek yang lainnya tampak mengalami penurunan skor academic anxiety pada saa posttest vs follow-up. Hal ini menunjukkan bahwa active music therapy yang dirasakan oleh kelima subyek lainnya tidak hanya bertahan dalam jangka waktu yang pendek dan jika dilihat dari intensitas dalam memainkan musik, kelima subyek memainkan musik dalam jumlah yang bervariasi selama dua minggu.

\section{SIMPULAN}

Dalam penelitian ini dapat disimpulkan bahwa melalui konseling kelompok pendekatan CBT dengan teknik passive music therapy dan active music thera teknik passive music therapy dan active music therapy dapat secara efektif mereduksi academic anxiety
mahasiswa BK UnikaAtma Jaya. Berdasarkan hal tersebut, mahasiswa BK Unika tma Jaya. Berdasarkan hal tersebut, temuan penelitian ini dapat memberikan pemahaman baru di Indonesia, bahwa penggunaan pendekatan konseling konvensional yang diintegrasikan dengan music therapy terbukti efektif dalam mereduksi academic anxiety mahasiswa penyusun skripsi.

\section{DAFTAR PUSTAKA}

Atiwannapat, P., Thaipisuttikul, P., Poopityastaporn, P., Katekaew, W. (2016). Active versus receptive group music therapy for major depressive disorder- $\mathrm{A}$ pilot study. Complementary therapies in medicine, 26, 141-145.

Baker, F. A., Gleadhill, L. M., \& Dingle, G. A. (2007) Music therapy and emotional exploration: Exposing substance abuse clients to the experiences of non-drug-induced emotions. The Arts in Psychotherapy, 34(4), 321-330

Bibb, J., Castle, D., \& Newton, R. (2015). The role of music therapy in reducing post meal related anxiety for patients with anorexia nervosa. Journa of eating disorders, $3(1), 50$.

Bradley, L. J., Whiting, P., Hendricks, B., Parr, G., \& Jones Jr, E. G. (2008). The use of expressive techniques in counseling. Journal of Creativity in Mental Health, 3(1), 44-59.

Capuzzi, D., \& Gross, D. R. (2011). Counseling and psychotherapy: Theories and intervention (5th ed.). New Jersey: Merril Prentice Hall.

Çiftçi, H., \& Öztunç, G. (2015). The effect of music on comfort, anxiety and pain in the intensive care unit: a case in Turkey. International Journal of Caring Sciences, 8(3), 594.

Djohan. (2010). Respon emosi musikal. Bandung: Lubuk Agung.

Fox, E. I., \& McKinney, C. H. (2015). The Bonny method of guided imagery and music for music therapy interns: A survey of effects on professional and personal growth. Music Therapy Perspectives, 34(1), 90-98.
Fredenburg, H. A., \& Silverman, M. J. (2014). Effects of cognitive-behavioral music therapy on fatigue in patients in a blood and marrow transplantatio unit: A mixed-method pilot study. The Arts in Psychotherapy, 41(5), 433-444.

Gibson, R. L., Mitchell, M. H. (2011). Bimbingan dan konseling (ed. 7). Yogyakarta: Pustaka Pelajar

Gladding, S. T. (2016). The creative arts in counseling. John Wiley \& Sons.

Gutiérrez, E. O. F., \& Camarena, V. A. T. (2015). Music therapy in generalized anxiety disorder. The Arts in Psychotherapy, 44, 19-24.

Ilie, G. (2013). Effects of individual music playing and music listening on acute-stress recovery. Canadian Journal of Music Therapy, 19(1), 23-46

Laura, D., Sylvie, J., \& Aurore, S. (2015). The effects of music therapy on anxiety and depression. Ann Depress Anxiety, 2(4), 1057.

Lilley, J. L., Oberle, C. D., \& Thompson Jr, J. G. (2014). Effects of music and grade consequences on tes anxiety and performance. Psychomusicology Music, Mind, and Brain, 24(2), 184

Mucci, R., \& Mucci, K. (2002). The healing sound of music. Jakarta: PT. Gramedia Pustaka Umum.

Ottens, A. J. (1991). Coping with academic anxiety. The Rosen Publishing Group.

Rogers, D. R., Ei, S., Rogers, K. R., \& Cross, C. L. (2007). Evaluation of a multi-component approach to cognitive-behavioral therapy (CBT) using guided visualizations, cranial electrotherapy stimulation, and vibroacoustic sound. Complementary therapies in clinical practice, 13(2), 95-101.

Rosanty, R. (2014). Pengaruh musik mozart dalam kripsi. Journal oda mahasiswa yang sedang Community Psychology, 3(2), 71-78.

Sharf, R. S. (2015). Theories of psychotherapy \& counseling: Concepts and cases. Cengage Learning.

Situmorang, D. D. B. (2016). Hubungan antara potens kreativitas dan motivasi berprestasi mahasisw program studi bimbingan dan konseling angkatan 2010 FKIP Unika Atma Jaya. Jurnal Bimbingan Konseling Indonesia, 1(1), 6-9.

Situmorang, D. D. B. (2017). Efektivitas pemberian layanan intervensi music therapy untuk mereduksi cademic anxiety mahasiswa terhadap skripsi. BKI (Jurnal Bimbingan Konseling Indonesia), 2(1), 4-8.

Situmorang, D. D. B. (2018). Keefektifan Konseling Kelompok Cognitive Behavior Therapy (CBT) Dengan Teknik Passive dan Active Music Therapy terhadap Academic Anxiety dan Selfefficacy. Unpublished master's thesis). Program 
Pascasarjana, Universitas Negeri Semarang, Indonesia.

Situmorang, D. D. B. (2018). Mahasiswa mengalami academic anxiety terhadap skripsi? Berikan konseling cognitive behavior therapy dengan musik. Jurnal Bimbingan dan Konseling ArRahman, 3(2), 31-42.

Skudrzyk, B., Zera, D. A., McMahon, G., Schmidt, R., Boyne, J., \& Spannaus, R. L. (2009). Learning to relate: Interweaving creative approaches in group counseling with adolescents. Journal of Creativity in Mental Health, 4(3), 249-261.

Vargas, M. E. R. (2015). Music as a resource to develop cognition. Procedia-Social and Behavioral Sciences, 174, 2989-2994.

Vianna, M. N., Barbosa, A. P., Carvalhaes, A. S., \& Cunha, A. J. (2011). Music therapy may increase breastfeeding rates among mothers of premature newborns: a randomized controlled trial. Jornal de Pediatria, 87(3), 206-212.

White, S. D., \& Davis, N. L. (2011). Integrating the expressive arts into counseling practice (Theorybased interventions). New York: Springer Publishing Company.

Wibowo, M. E. (2005). Konseling Kelompok Perkembangan. Semarang: UNNES Pers.

Zarate, R. (2016). Clinical Improvisation and its effect on anxiety: A multiple single subject design. The Arts in Psychotherapy, 48, 46-53.

Zhang, Y., Cai, J., An, L., Hui, F., Ren, T., Ma, H., \& Zhao, Q. (2017). Does music therapy enhance behavioral and cognitive function in elderly dementia patients? A systematic review and meta-analysis. Ageing research reviews, 35, 1-11. 